\title{
Does religion affect alcohol and tobacco use among students at
}

\section{North-West University, South Africa?}

\author{
${ }^{1}$ Acheampong Yaw Amoateng \\ ${ }^{2}$ Boitumelo Marilyn Patience Setlalentoa \\ ${ }^{1,2}$ Christopher Udomboso \\ ${ }^{1}$ School of Research and Post-Graduate Studies, North West University (Mafikeng Campus), \\ South Africa \\ ${ }^{2}$ Department of Statistics, University of Ibadan, \\ Ibadan, Nigeria. \\ yaw.amoateng@nwu.ac.za
}

\begin{abstract}
The present study used multidimensional measures of religion to assess religion's influence in engendering positive behaviours as measured by alcohol and tobacco use among a sample of undergraduate students at the North-West University in South Africa. Multinomial logistic regression model was used to examine the effect of religion on youth alcohol and tobacco use. Zero-order correlations showed that measures of religion not only correlated positively with each other, but they correlated negatively with both current use of alcohol and tobacco. Religious affiliation was insignificant, but self-rated religiosity was positively associated with drinking among females who reported that they always drink alcohol, frequency of church attendance increased the odds of drinking among females who reported that they never drink compared to those who reported that they drink occasionally. Social class, as measured by father's education was negatively associated with both alcohol and tobacco use. On the whole, religious commitment continues to act as the protective factor against these two anti-social behaviours of the youth.
\end{abstract}

Keywords: Religion, Religiosity, Spirituality, Belief in God, Youth Behaviours.

\section{Introduction}

While in previous years youth has been conceptualised as a problematic period (deficit model) in the life cycle, in recent decades there has emerged a new and positive conception of the youth as a result of the increasingly more collaborative contributions of scholars from different disciplines, practitioners and policy makers (Gore 2003; Lerner, Brentano, Dowling, \& Anderson 2002; Wheeler 2000; Roth, Brooks-Gunn, Murray, \& Foster 1998;). Consistent with this new thinking about youth development, research attention to spiritual and religious development of youth has been rising since the mid-1990s, particularly within the study of child development and positive youth development (Boyatsis 2005; Flanagan \& Sherrod 1998; Lerner, Roeser, \& Phelps 2008; Sherrod, Flanagan, \& Youniss 2002). This positive approach to youth problems in contemporary developmental thinking projects the notion that healthy adolescent development entails a merger of moral and civic identity which results in engagement with such civil society institutions as religion by the youth (Crompton 1998; Lerner et al. 2002).

In the face of the proliferation of the myriad developmental challenges that are confronting the youth in contemporary society, can this new thinking about youth development help us to understand such problems as alcohol and tobacco use? In South Africa, youth drinking and tobacco use have become the exemplar of the anti-social behaviours facing the youth. It has been estimated by the World health Organisation (WHO) (20II) that the consumption of alcohol in South Africa is in excess of 5 billion litres per year (20II), a situation which makes the country one of the countries that is experiencing a problem with alcohol use and abuse. According to South Africa's National Drug Master Plan (2006-20II), alcohol is the primary drug of abuse by men and female adults and youth with the choice to use these two substances being made during adolescence. In 
fact, some studies have estimated that addiction to tobacco takes place? at age 15 and younger (Chauke et al. 20I5; Clarke 20I6; Morojele et al. 2006; Peltzer et al. 20।2; Seggie 20I2).

It is against the background of the role of religion in engendering positive youth behaviour that we undertake the present study. The aim of the study is to test this new paradigm of youth development by examining the effect of religion on cigarette smoking and alcohol consumption in a sample of undergraduate students at the North-West University in South Africa. While for millennia religion had been a moral force in making social order possible, the emergence of modernisation processes such as the enlightenment and increasing secularisation of society in the $18^{\text {th }}$ century in Europe and elsewhere had had the effect of loosening the moral bonds and ethos religion engendered. In recent decades however, there has been visible manifestation of religious resurgence in several Western and non-Western societies across the globe. Several scholars in the West and other contexts like Africa have written about this resurgence of religion (Bell 1979; Ellis and Haar 2004; Ellis 2006; Haar and Ellis 2006; Jang and Johnson 200I; Mainous et al. 200I; Miller et al. 2000; Pew Research Center 2015; Ream 2003; Weber 1992).

\section{Aim and Rationale of Study}

It is against the background of these pioneering works to demonstrate the effect of religious ideas on the material conditions of adherents that we undertake the present study. Specifically, the aim of the study is to assess the effect of religion on two youth risk behaviours - cigarette smoking and the use of alcohol-using a sample of undergraduate students at the North-West University in South Africa. The substance use and abuse literature in South Africa is replete with empirical studies that have examined the use of both tobacco and alcohol. For example, Madu and Matla (2003) studied alcohol drinking behaviour among high school adolescents in Polokwane, Limpopo Province, and found a prevalence rate of $20 \%$ of illicit drug, II\% of cigarette smoking and $39 \%$ for alcohol consumption among the participants.

The 2002 National Youth Risk Behaviour Survey of 10699 learners showed that $29 \%$ of black males and $17 \%$ of females in Grade 9-II reported binge drinking (Reddy et al, 2003). Parry et al. (2002) reported the results of a study of learners drinking that showed prevalence of heavy drinking in three cities, Cape Town, Durban and Port Elizabeth. In a study in the North West Province of South Africa, Setlalentoa et al. (20I0) observed that respondents started to drink as early as 10 years of age, although http://aps.journals.ac.za the majority started at age 20 years, a finding which is consistent with that of Obot et al. (2003) in Nigeria which found an average age of first consumption of I 3.2 years.

Even though the literature on the relationship between religion and youth risk behaviours have proliferated in recent years especially, in South Africa (e.g. Amoateng et al. 2006; Flisher et al. 1996; Ghuman and Hoque; Morojele et al. 2006; Pettifor et al. 2004; PrüDderman and Flisher 2008; Onya et al. 2015; Ward et al. 2008; Wild et al. 2008), many of the extant studies have either used religion as a control variable or used a single dimension of religion to look at various youth risk behaviours. For example, Amoateng, Kalule-Sabiti and Arkaah (2014) examined the effect of religion but this study only examined the effect of the dimension of religiosity on adolescent sexual behaviours.

While Amoateng, Kalule-Sabiti and Narayan (2007) assessed the effect of religion on adolescent substance use behaviours, they assessed the effect of only religious affiliation and religiosity, ignoring the fact that religion is a multidimensional concept. Moreover, studies in other contexts and South Africa have addressed the relations of substance use with several socio-demographic factors, including religiosity and academic performance (e.g. Ghuman and Hoque 2015; Onya et al. 2012; Peltzer et al. 2002). Besides the fact that very few studies have used multiple measures of religion to examine their effects on youth alcohol and tobacco use, Peltzer et al. (2002) and have rightly observed that studies that use samples of youth at tertiary institutions are rare; most of the studies in South Africa are based on samples of adolescents in high or secondary schools.

It is this void in the existing literature that the current study sought to fill. In this study, we assess the effects of five dimensions of religion on cigarette smoking and alcohol consumption among undergraduate students at the North-West University in the North West Province of South Africa. Since religion is a multidimensional concept, efforts to examine the role of religion in behavioural outcomes must not only seek to be useful in the correlational domain, but must also be nuanced enough to be useful in the domain of theory building. The present study essentially builds on the existing body of knowledge on the religion-youth risk behaviours nexus by using multiple dimensions of religion to examine this relationship with a sample of college students. The paucity of studies on alcohol and tobacco use by university students in South Africa is difficult to fathom in the face of such evidence that this is the period during which most addiction to Nicotine begins. Also, it's been observed that recent epidemics in the use of illicit drugs have been most

3213 
pronounced among teenagers and young adults (Bachman and Wallace (200I). Moreover, there is evidence that during this period of the life span, many changes, opportunities, and risks occur, making the structures and guidelines provided by religious commitment especially important in helping young people resist such temptations (Spilka 199I). Finally, the importance of a study focusing on how religion can impact the risk behaviours of college students in South Africa cannot be overemphasised in the face of such stressors as youth unemployment, crime, poverty and violence in contemporary South African society.

\section{Theoretical Framework and Review of the Empirical Literature}

For millennia religion has acted as a social control mechanism for adherents regardless of the particular religious organisation. For example, Hirschi (1969) has argued that apart from providing opportunities for learning law-abiding attitudes and behaviours, involvement in conventional activities such as religion takes time that would otherwise be spent in deviant activities. Rohrbaugh and Jessor (1975) have similarly asserted that religious involvement is one type of conventional activities that teach antidrug attitudes and provides controls against drug abuse. Moreover, religion provides multiple and diverse functions for an individual ranging from providing meaning to a person's life, to obtaining a sense of personal fulfilment, to securing access to social contacts and interpersonal relationships, to offering a set of standards against which to judge one's actions (Jessor et al. 1968). It is within the context of the dual role of religion as an agent of socialisation and a social control mechanism that we assess the relationship between religion and cigarette smoking and alcohol consumption among university students in the present study.

Yet, the existing body of knowledge on the subject of the relationship between religion and youth smoking and drinking is at best inconsistent (Amey et al. 1996; Francis 1997; Mann et al. 2007). As far as religious affiliation is concerned, one body of empirical studies has found significant differences between members of different religious organisations, especially, between Protestants and Catholics or between members of different Protestant denominations (Francis 1997).

A large national study of smoking in the general population of the United States revealed that the likelihood of smoking decreased significantly as religious attendance increased (Gillum 2005). Specifically, frequent attenders were approximately half as likely to smoke as infrequent attenders regardless of gender and race. Mann et al. (2007) 3214 similarly found a negative association between religiosity and recent tobacco use. Specifically, they found that a one standard deviation increase in overall religiousness was associated with a greater than $40 \%$ reduction in the odds of recent tobacco use. There is some evidence for religiosity as a protective factor shown by studies that have found that measures of religiosity are inversely correlated with indices of adolescent substance use (Wallace and Williams 1997).

Also, in the United States, Amey et al. (1996) reported an inverse relationship between measures of frequency of attendance at religious services and alcohol and other substance use. Two recent studies in the United States, one among Appalachian women and one among low-income whites and AfricanAmerican women, demonstrated significant association between religiosity and spirituality and smoking by pregnant women (Jesse and Reed 2004; Jesse et al. 2006). In both studies, religiosity (measured by participated religious service attendance) was associated with decreased levels of smoking. Moreover, spirituality was significantly associated with lower levels of smoking in Appalachian women, but not in the African-American and low-income white women. In a study that examined the relationship between religion and alcohol consumption in Australia, Bouma and Dixon (1987) observed that $37 \%$ of those belonging to theologically right wing Protestant groups totally abstained, compared with $20 \%$ of those belonging to the Presbyterian, Methodist and Uniting churches.

As far as South Africa is concerned, in a study involving first-year students at the University of the North, Peltzer, Malaka and Phaswana (2002) found that low scores on religiosity and being Christian were among the factors that predicted tobacco use, while low scores on religiosity and being a Christian similarly predicted alcohol use among the students. Moreover, in a study on the effect of religious beliefs on substance use among South African high school students, Ghuman and Hoque (2015) found that rates of alcohol and drug use were common among nonreligious subjects than among religious subjects. In a study of prevalence and correlates of substance use among South African primary care clinic patients, Ward et al. (2008) used religious affiliation and frequency of religious activities to assess religion's effect on hazardous drinking and found religion to be a protective factor against this behaviour.

However, other studies have found no relationship or weak relationship between denominational preference and adolescent drinking (Nusbaumer 198I), while in South Africa, a study of adolescent alcohol use by Onya et al. (2012) found that for students who attended religious services, the http://aps.journals.ac.za 
odds of ever having used alcohol were double those of students who did not attend religious services. In the current study, we test the following hypotheses:

Hypothesis \#I: Youth who profess other religious affiliations will be less likely than those who are either Protestant or Catholic to smoke or drink alcoholic beverages.

Hypothesis \#2: Youth who attend church/mosque/synagogue/temple frequently will be less likely to use tobacco and alcohol than those who do not attend church/mosque/synagogue/temple frequently.

Hypothesis\#3: Youth whose family members attend church/mosque/synagogue/temple frequently will be less likely to smoke or drink alcohol than those whose family members are not frequent attenders of church/mosque/synagogue/temple so frequently;

Hypothesis\#4: Youth who perceive religion as important in their lives will be less likely to use alcohol and tobacco than those who do not perceive religion as important in their lives;

Together with the five dimensions of religion, index of spirituality and the above-mentioned control variables will be examined to see how they impact youth alcohol and tobacco use with the sample of undergraduate students at the North-West University in South Africa.

\section{Data and Methods}

The data for the current study come from the Religion and Positive Youth Development Project an initiative of Population Studies Department of the North-West University (Mafikeng Campus). Both probability and non-probability sampling methods were used to interview a total of I 430 undergraduate students across the three campuses of the University (i.e. Mafikeng, Potchefstroom and Vaal campuses). In the probability sampling method, stratified random sampling design was employed by disaggregating the samples from each campus by faculties using proportional allocation to size based on the population of students by faculties. In the nonprobability sampling method, each faculty samples were disaggregated by year of study.

The sample numbers allocated to each year of study were random. Generally, the least sample numbers were allocated to the first year students, while the greatest sample numbers were allocated to the fourth year students. Finally, in selecting the students to be included in the sample, convenience sampling was used whereby trained students interviewed the numbers of students in each faculty, school, and gender as determined a priori through the stratified random sampling procedure. Out of the target sample of 1430 students, 847 students http://aps.journals.ac.za completed the interview, yielding a response rate of $59 \%$. Respondents were subjected to a battery of questions relating to issues such as religious affiliation, religiosity, spirituality, sexuality, political participation, attitudes towards foreigners and attitudes towards and use of various licit and illicit substances. Data collection took place between September and November, 2015.

\section{Statistical analysis and measures of variables}

Both descriptive and inferential statistical techniques were employed in the analysis of the data to examine the effect of religion on university students' current use of alcohol and tobacco (cigarette) in the study. Specifically, we employed simple frequencies, means, and Spearman's correlations for the univariate and bivariate analyses respectively, while the Multinomial Logistic Regression model was used in the multivariate analyses, the Multinomial technique is a classification method that generalizes logistic regression into multiclass problems, that is, with more than two possible discrete outcomes (Greene 20I2). It is a model that is used to predict the probabilities of the different possible outcomes of a categorically (or nominally) distributed dependent variable, given a set of independent variables (which may be real-valued, binary-valued, categorical-valued, and so on). Its assumptions include that data are case specific; that is, each independent variable has a single value for each case, and that the dependent variable cannot be perfectly predicted from the independent variables for any case.

Moreover, the independent variables need not be statistically independent from each other while collinearity is assumed to be relatively low, as it becomes difficult to differentiate between the impacts of several variables if this is not the case (Belsley 1991). Multinomial logistic regression uses a linear predictor function $f(k, i)$ to predict the probability that observation $i$ has outcome $k$, of the following form:

$$
\begin{aligned}
& f(k, i)=\beta_{0, k}+\beta_{1, k} x_{1, i}+\beta_{2, k} x_{2,1}+\cdots+ \\
& \beta_{M, k} x_{M, i},
\end{aligned}
$$

For the Dependent variable, we examined both current use of tobacco and current use alcohol separately. To measure current use of tobacco and alcohol, students were asked: (a) Do you engage in smoking cigarette; (b) Do you engage in drinking alcohol? The response categories were I 'Never' 2 'Sometimes' and 3 'Always'. To assess the role of religion in the life of the youth, we examined five dimensions of religion: (I) Self-rated religiosity. This was measured by asking the respondent, "How religious do you consider yourself to be?" The response was a five-point Likert scale ranging from 
"Not at all religious" to "Extremely religious"; (2) Perception of the importance of religion in one's life/a family's life which was measured by asking the student: "How important is religion in your life/your family's life?" The responses were a five-point Likert scale ranging from "Not at all important to "Extremely important" (3) Frequency of church attendance, was measured by a five-point Likert scale ranging from "Never" to "Fairly regularly".

Students were asked to indicate "How often do you and your family attend church/mosque/temple/synagogue services?"

Religious affiliation was measured by three categories. For this dimension, students were asked to indicate the religious organisation they belonged to and three broad affiliations were measured: Christian (Protestant), Christian (Catholic) and Other (Muslim, Hindu, African Traditional Faith, Judaism, no affiliation and other) ${ }^{i}$ and (5) Belief in God which was measured by a four-item Likert scale: "I believe in a higher Power/Universal intelligence"; "I have a relationship with a higher power/universal intelligence"; "My faith in a higher power helps me cope during challenges in my life" and "Prayer is an integral part of my spiritual nature......". The responses ranged from I ="Strongly Disagree" to 6="Strongly Agree". Factor analysis was used to create an index of belief in God after assessing its reliability with the Cronbach's Apha Reliability Coefficient (.84I). Besides these five dimensions of religion, we also controlled for "Spirituality".

Spirituality was assessed using the Spiritual Perspective Scale, which measures views and activities that provide a sense of transcendence and connectedness to a greater purpose. Spirituality was an additive index of 22 items measured on a Likert scale and the responses ranged from I"Strongly Disagree to 6 "Strongly Agree. Sample items included "I find meaning in my life", I have a sense of purpose", "At times I feel at one with the universe", "The earth is sacred", I believe that all living creatures deserve respect". Both index of Belief in God and index of Spirituality were measured as summated variables of the respective items. The use of multiple measures of religion is consistent with Lam's (2002) view that because of the difference between praying, believing, and attending a congregation, they should all be included.

The respondent's age, mother's educational attainment, father's educational attainment, family structure, family's socioeconomic status, religious affiliation, parental religion as measured by their church attendance and importance of religion in their lives were used as control variables in the analysis. Age was measured as a continuous variable, while both mother's and father's educational attainment 3216 were measured at the ordinal level with the question: Please indicate the highest level of your mother's/father's education. The responses ranged from I'No education to 7'Postgraduate degree'. Family structure was measured at the nominal level with the question: At home, which parents or guardian do you live with? The responses ranged from I'Living with both biological parents at home' 2' Living with a single parent' 3'living with other relatives'. Family's socioeconomic status was measured at the ordinal level with the question: How would you describe your family's socioeconomic status compared to other families in the area where you live? The responses ranged from I'Poorer than most 2 'About the same as most 3'Richer than most'. The Multinomial regression model is employed to examine the effect of religion on the use of the two substances net of the effects of other variables.

\section{Results}

Table I shows the description of the sample characteristics and current alcohol and tobacco use respectively. Thirty-five percent were first year students, while 35 percent of them were in either third or fourth year; second year students constituted 27. percent of the total sample, while 3 percent of the students were postgraduate/diploma students. As far as tobacco use is concerned, nearly three-quarters (7I.\%) of the respondents reported that they did not smoke cigarettes, while $17 \%$ and $11 \%$ respectively of the students reported that they sometimes smoked and always smoked.

Males smoked more than females as evidenced by the fact that nearly eight out ten $(79 \%)$ of the females indicated that they had never smoked cigarette compared to only $62 \%$ of their male counterparts. Conversely, $18 \%$ of the males reported that they always smoked cigarette compared to only $6 \%$ of the females. As far as alcohol use goes, $52 \%$ and $16 \%$ respectively of the students reported that they either smoked sometimes or they always smoked. Drinking alcoholic beverages was more popular amongst the students than smoking cigarette, while males drank more than females. For example, while $71 \%$ of the students reported that they never smoked, slightly less than one-third (32\%) of them reported that they had never drank. As far as gender goes, while almost onefifth (19.) of the males reported that they always drank, the same was true of only 13\% of their female counterparts.

The majority of the respondents were black African $(88.2 \%)$ followed by whites (7.4\%) and coloureds (3.7\%); Indian/Asian and others constituted $(0.7 \%)$ of the sample. Sixty-three percent

http://aps.journals.ac.za 
of the respondents were Protestant, followed by Catholics who constituted 24\%. Adherents of traditional religious beliefs constituted $3 \%$ of the sample, while students without any religious affiliation constituted $6 \%$ of the sample; other religious groups constituted only $7 \%$ of the sample. Over fifty percent (55\%) of the respondents stayed with both parents at home during university holidays, while slightly over one-third of them (34\%) stayed with a single parent; $12 \%$ of the respondents stayed with other relatives.

Table I: Distribution of Sample Characteristics

\begin{tabular}{|c|c|c|c|c|c|}
\hline \multirow[b]{2}{*}{ Variable } & \multicolumn{2}{|l|}{ Male } & \multicolumn{2}{|l|}{ Female } & \multirow{2}{*}{ Total } \\
\hline & Number & $\%$ & Number & $\%$ & \\
\hline \multicolumn{6}{|l|}{ Year of Study } \\
\hline First Year & 113 & 30.5 & 117 & 38.2 & 34.8 \\
\hline Second Year & 101 & 27.3 & 127 & 27.4 & 27.4 \\
\hline Third \& Fourth Year & 146 & 39.5 & 148 & 32.0 & 35.3 \\
\hline Postgraduate/Diploma & 10 & 2.7 & 11 & 2.4 & 2.5 \\
\hline \multicolumn{6}{|l|}{ Current Smoking status } \\
\hline Never & 223 & 61.9 & 359 & 78.9 & 71.4 \\
\hline Sometimes & 71 & 19.7 & 69 & 15.2 & 17.2 \\
\hline Always & 66 & 18.3 & 27 & 5.9 & 11.4 \\
\hline \multicolumn{6}{|l|}{ Current Drinking status } \\
\hline Never & 94 & 26.1 & $17 \mid$ & 37.4 & 32.4 \\
\hline Sometimes & 197 & 54.7 & 226 & 49.5 & 51.8 \\
\hline Always & 69 & 19.2 & 60 & 13.1 & 15.8 \\
\hline \multicolumn{6}{|l|}{ Race } \\
\hline Black African & 323 & 88.3 & 401 & 88.1 & 88.2 \\
\hline White & 29 & 7.9 & 32 & 7.0 & 7.4 \\
\hline Coloured & 13 & 3.6 & 13 & 3.6 & 3.7 \\
\hline Others & 1 & 0.0 & 5 & 0.92 & 0.7 \\
\hline \multicolumn{6}{|l|}{ Religious affiliation } \\
\hline Christian-Protestant & 182 & 57.2 & 279 & 67.2 & 62.9 \\
\hline Christian-Catholic & 78 & 24.5 & 97 & 24.4 & 23.9 \\
\hline Traditional African & II & 3.5 & 7 & 1.7 & 2.5 \\
\hline No affiliation & 28 & 8.8 & 9 & 2.2 & 5.5 \\
\hline Other & 19 & 6.0 & 23 & 5.5 & 5.7 \\
\hline \multicolumn{6}{|l|}{ Family structure } \\
\hline Both Parents at home & 192 & 54.4 & 248 & 54.7 & 54.6 \\
\hline Single parent & 118 & 33.4 & 154 & 34.0 & 33.7 \\
\hline Other relatives & 43 & 12.2 & 51 & 11.3 & 11.7 \\
\hline \multicolumn{6}{|l|}{ Family SES } \\
\hline Poorer than most & 81 & 22.1 & 84 & 18.2 & 19.9 \\
\hline About the same as most & 249 & 67.8 & 328 & 71.1 & 69.7 \\
\hline Richer than most & 37 & 10.1 & 49 & 10.6 & 10.4 \\
\hline
\end{tabular}

Table 2 shows the results of the Pearson Rank Correlation Coefficients for males and females for the predictor and outcome variables. On the whole, most of our expectations about the effect and directions of the influence of the variables are confirmed by these results. Firstly, the two outcome variables, namely, cigarette smoking and alcohol drinking are positively associated for both males and females. Specifically, the correlation coefficient between current use of cigarette and current consumption of alcohol is 0.419 and 0.47 I for males and females respectively.

Secondly, most of the religion variables are significantly associated with each other in the expected direction. For example, youth self-rated religiosity is significantly and positively associated with the importance of religion in their lives $(0.479$ and 0.459 for males and females respectively), with frequency of church attendance $(0.5 \mathrm{II}$ and $0.39 \mathrm{I}$ for males and females respectively), with frequency of church attendance by family members $(0.245$ and 0.258 for males and females respectively), with belief in God (0.267 and 0.249 respectively) and with spirituality index ( 0.254 and 0.191 respectively).

Thirdly, and as expected, most of the religion variables are negatively associated with smoking and drinking. For example, frequency of church attendance by the respondent is negatively associated with current use of alcohol for both males and females ( -0.198 and -0.225 respectively) and smoking 
of cigarette $(-0.146$ and -0.238 respectively). But, frequency of church attendance by family members is negatively associated with cigarette smoking only among females $(-0.107)$. Contrary to expectation, however, both father's and mother's

Table 2: Zero-Order Correlation Coefficients of Predictor and Outcome Variables

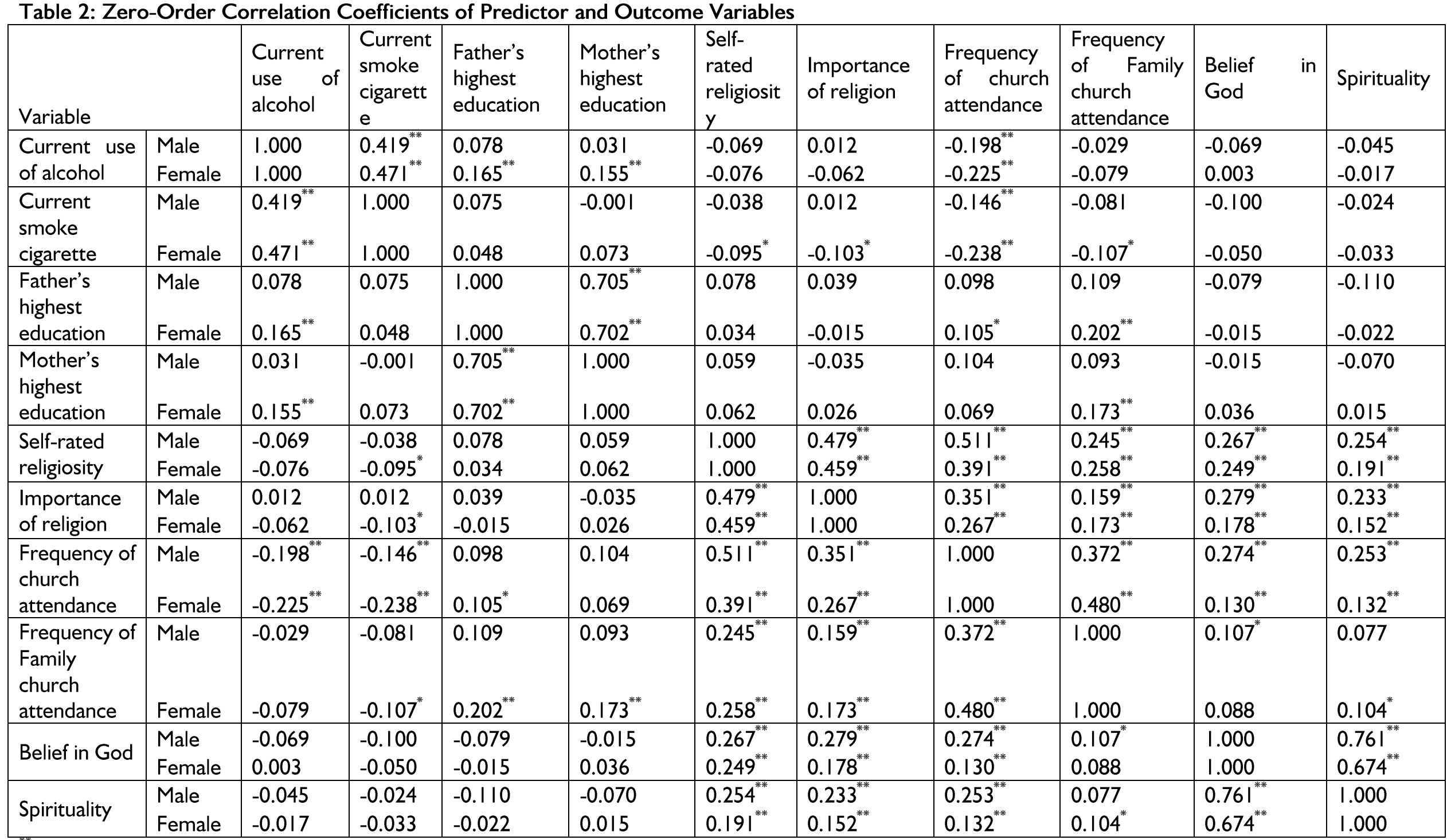

** Correlation is significant at the $1 \%$ level (2-tailed)

${ }^{*}$ Correlation is significant at the $5 \%$ level (2-tailed)

3218 education are positively associated with alcohol drinking by females $(0.165$ and 0.155 respectively). 
Table 3 shows the results of the multinomial analysis of the factors that affect current alcohol and tobacco use among the youth by gender. Contrary to our expectation, the data did not support our hypothesis that youth who were affiliated to a religious organisation would use alcohol and tobacco less than those who were not affiliated was not supported. However, consistent with our expectation, the respondent's frequency of church attendance is negatively associated with drinking among both males and females, although the respondent's family frequency of church attendance is not statistically significant in predicting tobacco and alcohol use amongst the students as stipulated by hypothesis \#3.

For the respondent's frequency of church attendance, table 3 shows that compared to those who report occasional drinking, youth who attend church frequently are 0.787 and 0.768 times less likely to drink alcohol among males and females respectively compared to their counterparts who reported that they always drank. However, females who attend church frequently those who report that they always drink are 1.210 times more likely to drink compared to their counterparts who report occasional drinking. Females who report that they never smoke and attend church frequently are I.32I times more likely to smoke compared to their counterparts who report occasional smoking. Contrary to our expectation, the data did not support hypothesis \#4 which stipulated that the importance of religion in the youth's life will be a significant predictor of youth alcohol and tobacco use. However, females who report that they always drink alcohol are 1.62 times more likely to drink alcohol compared to their counterparts who drink occasionally as self-rated religiosity increases. But, for those who said that they always drink alcohol, findings from self-rated religiosity shows that the females are 1.62I times more likely to drink compared to those who said that they drink occasionally.

The only control variables that emerge as significant predictors of tobacco and alcohol use among the students are father's educational attainment and spirituality. Table 3 shows that father's educational attainment is negatively associated with current use of alcohol but not current use of tobacco among both males and females. Specifically, father's educational attainment reduces the odds of drinking 0.805 times among males and 0.79 I times among females, of those who indicated that they never drink alcohol in comparison to those who said that they only drink occasionally. Males who report high levels of spirituality are 0.600 times less likely to smoke among those who report that they never smoke compared to their counterparts who smoke occasionally. Of the variables in the model, religious affiliation, family structure and family socioeconomic status and mother's educational attainment were all insignificant in predicting the use of alcohol and tobacco among males and females in the sample (Not shown).

Table 3: Multinomial Analysis of current use of alcohol and tobacco (ORs)

\begin{tabular}{|c|c|c|c|c|c|c|}
\hline \multirow{3}{*}{$\begin{array}{l}\text { Variable } \\
\text { Father's highest } \\
\text { education }\end{array}$} & \multirow[b]{3}{*}{$\begin{array}{l}\text { Male } \\
\text { Female }\end{array}$} & \multicolumn{2}{|c|}{ Current use of alcohol } & \multicolumn{3}{|c|}{ Current smoke cigarette } \\
\hline & & Always & Never & Always & Never & \\
\hline & & $\begin{array}{l}\text { I.067(0.820 } \\
\text { I.388) } \\
\text { I.054 } \\
\text { I.426) } \quad(0.779\end{array}$ & $\begin{array}{l}0.805^{*} \\
1.033) \\
0.791^{* *} \\
0.981)\end{array}$ & $\begin{array}{l}\begin{array}{l}\mathrm{I} .184(0857 \\
\mathrm{I} .636) \\
0.869 \\
\mathrm{l} .405)\end{array} \quad(0.538 \\
\end{array}$ & $\begin{array}{l}0.852 \\
1.104) \\
0.859 \\
1.142)\end{array}$ & $\begin{array}{l}0.658 \\
(0.646\end{array}$ \\
\hline Religiosity & $\begin{array}{l}\text { Male } \\
\text { Female }\end{array}$ & $\begin{array}{ll}0.998 & (0.695 \\
1.435) & \\
1.621^{* * *} & (1.027 \\
2.559) & \\
\end{array}$ & $\begin{array}{l}1.153(0.837 \\
1.589) \\
1.254 \\
1.711)\end{array} \quad(0.919$ & $\begin{array}{ll}1.417 & (0.930 \\
2.158) & \\
1.384 & (0.688 \\
2.785) & \\
\end{array}$ & $\begin{array}{l}1.212 \\
1.716) \\
0.997 \\
1.516) \\
\end{array}$ & $\begin{array}{l}(0.857 \\
(0.655\end{array}$ \\
\hline $\begin{array}{l}\text { Importance of } \\
\text { religion }\end{array}$ & $\begin{array}{l}\text { Male } \\
\text { Female }\end{array}$ & $\begin{array}{l}1.075 \\
1.319) \\
0.803 \\
1.219) \\
\end{array}$ & $\begin{array}{l}0.985 \\
1.226) \\
0.899 \\
1.167) \\
\end{array}$ & $\begin{array}{l}1.006 \\
1.267) \\
1.168 \\
2.202) \\
\end{array}$ & $\begin{array}{l}0.843 \\
1.033) \\
1.293 \\
1.877) \\
\end{array}$ & $\begin{array}{l}(0.688 \\
(0.89)\end{array}$ \\
\hline $\begin{array}{l}\text { Frequency of } \\
\text { church attendance }\end{array}$ & $\begin{array}{l}\text { Male } \\
\text { Female }\end{array}$ & $\begin{array}{l}0.787^{*} \\
1.025) \\
0.768^{* *} \\
0.986) \\
\end{array}$ & $\begin{array}{l}1.148 \quad(0.927 \\
1.421) \\
1.210 *(1.018 \\
1.437)\end{array}$ & $\begin{array}{l}0.794 \\
1.077) \\
0.729 \\
1.129) \\
\end{array}$ & $\begin{array}{l}1.118 \\
1.414) \\
1.321^{* *} \\
1.679) \\
\end{array}$ & $\begin{array}{l}(0.884 \\
(1.040\end{array}$ \\
\hline $\begin{array}{lr}\begin{array}{l}\text { Frequency } \\
\text { family }\end{array} & \text { of } \\
\text { church }\end{array}$ & $\begin{array}{l}\text { Male } \\
\text { Female }\end{array}$ & $\begin{array}{l}0.941 \\
1.174)\end{array}$ & $\begin{array}{ll}0.938 & (0.757 \\
1.163) & \\
\end{array}$ & $\begin{array}{l}1.042 \\
1.362)\end{array}$ & $\begin{array}{l}1.153 \\
1.437)\end{array}$ & $(0.924$ \\
\hline
\end{tabular}




\begin{tabular}{|c|c|c|c|c|c|c|c|c|c|}
\hline attendance & & $\begin{array}{l}1.135(0) \\
1.435)\end{array}$ & & $\begin{array}{l}1.065 \\
1.259)\end{array}$ & $(0.900$ & $\begin{array}{l}1.005 \\
1.452)\end{array}$ & $(0.696$ & $\begin{array}{l}1.066 \\
1.331)\end{array}$ & $(0.853$ \\
\hline Belief in God & $\begin{array}{l}\text { Male } \\
\text { Female }\end{array}$ & $\begin{array}{l}1.052 \\
1.627) \\
1.197 \\
2.363)\end{array}$ & $\begin{array}{l}(0.680 \\
(0.607\end{array}$ & $\begin{array}{l}1.231 \\
1.963) \\
1.091 \\
1.714)\end{array}$ & $\begin{array}{l}(0.772 \\
(0.694\end{array}$ & $\begin{array}{l}1.065 \\
1.750) \\
0.850 \\
2.410)\end{array}$ & $\begin{array}{l}(0.649 \\
(0.300\end{array}$ & $\begin{array}{l}1.410 \\
2.171) \\
1.135 \\
2.103)\end{array}$ & $\begin{array}{l}(0.916 \\
(0.612\end{array}$ \\
\hline Spirituality & $\begin{array}{l}\text { Male } \\
\text { Female }\end{array}$ & $\begin{array}{l}1.108 \\
1.764) \\
0.928 \\
1.733)\end{array}$ & $\begin{array}{l}(0.695 \\
(0.497\end{array}$ & $\begin{array}{l}0.733 \\
1 .(31) \\
0.753 \\
1.157)\end{array}$ & $\begin{array}{l}(0.476 \\
(0.49)\end{array}$ & $\begin{array}{l}0.874 \\
1.517) \\
1.178 \\
3.164)\end{array}$ & $\begin{array}{l}(0.503 \\
(0.439\end{array}$ & $\begin{array}{l}0.600^{* *} \\
0.960) \\
0.846 \\
(.503)\end{array}$ & $\begin{array}{l}(0.375 \\
(0.476\end{array}$ \\
\hline
\end{tabular}

Reference category: sometimes

${ }^{* *}$ Odds Ratio is significant at the $5 \%$ level (2-tailed)

* Odds Ratio is significant at the $10 \%$ level (2-tailed)

$$
\text { ( ) }=95 \% \text { Confidence Interval }
$$

\section{Discussion and Conclusion}

The time-honoured link between religion and myriad behaviours and attitudes such as family relations, delinquency, educational aspirations and health matters have been and continue to be well documented (Regnerus and Smith 2005). Even though the influence and role of religion in the mundane affairs of humankind declined during the period of the enlightenment as a result of the processes of modernisation and secularisation, there has been a resurgence of religiousness in both developed and developing societies in recent decades, a development which Bell (1979) has termed "The Return of the Sacred". It is against this background of the resurgence of religious influence in the lives of people in contemporary society that the current study was undertaken to examine how religion affects the drinking and smoking behaviours of students using a sample of undergraduate students across the three campuses of the North-West University in South Africa.

To accomplish this task, five dimensions of religion, an index of spirituality and selected control variables were measured to assess their impact on the respondents' current use of alcohol and tobacco. Zero-order correlations showed that measures of religion not only correlated positively with each other, but also correlated negatively with both current use of alcohol and tobacco among the youth. While the multinomial logistic regression analysis largely supported these findings about the impact of religion on the youth's substance use behaviours, the directions of influence were at best inconsistent. The study's hypothesis that religious affiliation would predict alcohol and tobacco use in a negative direction was not confirmed as affiliation to a religious organisation was not significantly associated with drinking by the youth. However, frequency of church attendance decreased the odds of drinking among both males and females who reported that they always drink and females compared to those who reported occasional drinking. On the other hand, frequency of church attendance increased the odds of drinking among females who reported that they never drink compared to those who only drink occasionally.

We found that self-rated religiosity was positively associated with drinking among females who reported that they always drink alcohol; it increased the odds of drinking by $62 \%$ compared to those who reported that they sometimes drink. This finding of positive association between religiosity and drinking by females is contrary to our hypothesis which was based on similar studies in South Africa (e.g. Peltzer et al. 2002; Ward et al. 2008). However, this finding is consistent with the findings of the study by Onya et al. (20I2) who found that for students who attended religious services, the odds of ever having used alcohol were double those of students who did not attend religious services.

The finding of positive association between selfrated religiosity and the drinking of alcohol among females and the inconsistent findings about the association between frequency of church attendance and the use of tobacco and alcohol by females may appear counterintuitive in the face of studies that have found negative association between these measures of religion and smoking and drinking by the youth (e.g. Abbott-Chapman and Denholm 200I; Amey et al. 1996; Regnerus and Smith 2005). It is possible that the findings are products of selection effects, social desirability bias in the survey responses, spurious artefact, or some combination of these factors (see e.g. Cochran, Wood and Arneklev 1994; Sloan, Bagiella, and Powell 1999).

For example, Regnerus and Smith (2005) have argued that the measured dimensions of religiosity in their study varied significantly by a variety of personality and demographic factors which in turn 
may have affected both the outcomes they examined as well as several factors they did not examine. Thus, according to them, religiosity is an endogenous concept, a situation which sensitise us to need to be concerned with its predictors and ideally, its causes. But, it is equally possible that these responses reflect the real experiences of the youth in regard to their behaviours vis a vis religion. This view in fact finds support in the work of other scholars. For instance, Smith and Denton (2005) cited in Sinha et al. (2007: 232??) concluded the following about the religious lives of American youth: "Youth, in general, do not so much as reject the religious affiliation or beliefs of their parents as much as fail to engage religion in a meaningful way". The negative association between father's education and current use of alcohol among both males and females is contrary to the findings in different contexts (Amoateng, Barber and Erikson 2006; Greenblatt 2000; Johnston and Bachman 1998; Pergamit, Huang and Lane 200I; Sinha et al. 2007), which found positive association between social class and youth use of substances, including tobacco and alcohol". The argument is that youth whose families are well off are able to afford such substances through the pocket money they are given.

In conclusion, while the current study supports the view that religion indeed engenders positive youth behaviours as far as tobacco use and consumption of alcohol are concerned. Moreover, the findings of the study have demonstrated that notwithstanding the inconsistent findings regarding the effect of religion on youth smoking and drinking, on the whole, religious commitment continues to act as the protective factor against these two anti-social behaviours of the youth. Moreover, this deterrence effect of religion is not limited to any specific developmental stage in the life cycle.

\section{References}

Abbot-Chapman, J., and Denholm, C. (200I). Adolescent risk activities, risk hierarchies and the influence of religiosity. Journal of Youth Studies, 4: 279-297.

Amey, C.H., Albrecht, S.L., and Miller, M.K. (1996).

Racial differences in adolescent

drug use: The impact of religion. Substance Use and Misuse, 31: |3| I-I332.

Amoateng, A.Y., Kalule-Sabiti, I., Arkaah, Y.J. (20I4).

The Effect of Socio-Demographic Factors on RiskySexual Behaviours ofAdolescents in the North West Province of South Africa. African Population Studies, 28 (I): 487-498.

Amoateng, A.Y., Kalule-Sabiti, I., and Narayanan, P. (2007). Substance Use and Sexual Behaviour among African Adolescents in the North-West
Province of South Africa. African Journal of Drug and Alcohol Studies, 6 (I): 27-38.

Amoateng, A.Y., Barber, B.K. and Erickson, L.D. (2006). Family predictors of

adolescent substance use: the case of high school students in the Cape Metropolitan Area, Cape Town, South Africa. Journal of Child and Adolescent mental Health, I8(I): 7-I5.

Bachman, J.G. and Wallace, J.M. (200I). Religion and Drug Use. Encyclopedia of

Drugs, Alcohol, and Addictive Behavior. http//www.encyclopedia.com/doc/IG23403 100399.html

Bell, D. (1978). The Return of the Sacred: The Argument about the Future of Religion.

Bulletin of the American Academy of Arts and Sciences, 3I (6): 29-55.

Belsley, D. (1991). Conditioning diagnostics: collinearity and weak data in regression. New York: Wiley. ISBN 978047I528890.

Benson, P.L. (1997). Spirituality and the adolescent journey.

Reclaiming children and youth, 5(4), 206-209.

Benson, P. L., Roehlkepartain, E. C., \& Rude, S. P. (2003). Spiritual development

in childhood and adolescence: Toward a field of inquiry. Applied Developmental Science, 7(3), 205-2I3.

Bouma, G.D. and Dixon, B.R. (1987). The religious factor in Australian Life,

MARC Australia, Melbourne.

Boyatzis, C. J. (2005). Religious and spiritual development in childhood.

In R. F. Paloutzian \& C. L. Park (Eds.), Handbook of the psychology of religion and spirituality (pp. 123-143). New York: Guilford Press.

Canda, E. R., \& Furman, L. D. (20/0). Spiritual diversity in social work practice (2nd ed.).

New York: Oxford University Press.

Canda, E. R., Nakashima, M., Burgess, V. L., Russel, R., \& Barfield, S. T. (2003).

Spiritual diversity and social work: A comprehensive bibliography with annotations (2nd ed.). Alexandria, VA: Council on Social Work Education.

Clarke, L., Beeghley, L. and Cochran, J.K. (1990). Religiosity, social class and alcohol

use: an application of reference group theory.

Clarke, E. 2016. Tobacco and Alcohol in South Africa. health Systems Trust.

Cochran, J.K., Wood, P.B., and Arneklev, B.J. (1994). Is the Religiosity-Delinquency

Relationship Spurious? A Test of Arousal and Social Control Theories. Journal of Research in Crime and Delinquency, 31: 92-I 23. 
Cochran, J.K., Beeghley, L.and Bock, E.W. (1988). Religiosity and alcohol

behaviour: an explanation of reference group theory. Sociological Forum, 3: 256-276.

Cohen, J. and Wills, T.A. (1985). Stress, social support, and the buffering hypothesis. Psychological Bulletin, 98: 310-357.

Coles, R. (1995). The profile of spirituality of at-risk youth. In T. Everson (Ed.),

The ongoing journey: Awakening spiritual life in atrisk youth (pp. 7-35). Omaha, NE: Boys Town Press.

Crompton, M. (1998). Children, spirituality, religion and social work.

Aldershot, England: Ashgate Publishing.

Derezotes, D. S. (2006). Spiritually oriented social work practice. Boston: Allyn and Bacon.

Desmond, S. A., Ulmer, J. T. \& Bader, C.D. 2013. Religion, Self-control and Substance Use. Deviant Behaviour, 34: 384-406.

Dziegielewski, S.F. 2004. The changing face of Health care social work: Professional

practice in managed behavioural health care. $2^{\text {nd }}$ Ed. New York: Springer Publishing Company, Inc.

Ellis, S. and Ter Haar, G. (2004). Worlds of Power: Religious Thought and Political

Practice in Africa. London and New York: C. Hurst \& Co. and Oxford University Press.

Erikson, E. (1968). Identity, youth and crisis. New York: Norton.

Flanagan, C., \& Sherrod, L. (Eds.). (1998). Political development: Youth growing up in a

global community. Journal of Social Issues, 54 (3).

Flisher, A.J., Ziervogel, C.F. , Chalton, D.O., Leger, P.H. and Robertson, B.A. (1996).

Risk-taking behaviour of Cape Peninsula high-school students. Part IX. Evidence for a syndrome of adolescent risk behaviour. South African Medical Journal, 86(9): 1090-1093.

Francis, L.J. (1997). The impact of personality and religion on attitude towards substance

use among 13-15 year olds. Drug and Alcohol Dependence, 44: 95-103.

Ghuman, S. and Hoque, M. (20I5). Effect of religious beliefs on substance use among

South African high school students. Southeast Asian Journal of Tropical Medicine and Public Health, 46(2): 345-353.

Gillum, R.F. (2005). Frequency of attendance at religious services and cigarette smoking

in American women and men: The Third National Health and Nutrition Examination Survey. Prev. Med, 4I: 607-6I3

Gore, A. (2003). Foreword: In R. M. Lerner \& P. L. Benson (Eds.). Developmental assets and asset-building communities: Implications for research, policy, and practice.

Norwell, MA: Kluwer Academic Publishers.

Greenblatt, J.C. (2000). Patterns of alcohol use among adolescents and associations with

emotional and behavioural problems [Electronic version]. Rockville, MD: Office of Applied Studies, Substance Abuse and mental Health Services Administration. Retrieved September 10, 2004, from

http://www.health.org/govstudy/adolemotion/

Greene, W. H. (20I2). Econometric Analysis (7th ed.). Boston: Pearson Education.

pp. 803-806. ISBN 978-0-273-75356-8.

Haar, G. and Ellis, S. (2006). The Role of Religion in Development: Towards a New

Relationship between the European Union and Africa. The European Journal of Development Research, I8 (3): 35I-367.

Hay, D., \& Nye, R. (1998). The spirit of the child. London: Fount.

Hirschi, T. (1969). Causes of Delinquency. Berkeley: University of California Press.

Jang, SJ, \& Johnson, B R. (200I). Heighborhood Disorder, Individual Religiosity and

Adolescent Use of Illicit Drugs: A Test of Multilevel Hypotheses. Criminology 39:109-143.

Jesse, E.D., Graham, M. and Swanson, M. (2006). Psychosocial and spiritual

factors associated with smoking and substance use during pregnancy in African-American and white low-income women. J Obstet Gynecol Neonatal Nurs, 35: 68-77.

Jesse, D.E. and Reed, P.G. (2004). Effects of spirituality and psychosocial well-being

on health risk behaviors in Appalachian pregnant women. I Obstet Gynecol Neonatal Nurs 33: 739-747.

Jessor, R., Grave, T.D., Hanson, R.C., and Jessor, S.L. (1968). Society, Personality, and

Deviant Behavior: A Study of a Tri-ethnic Community. New York: Holt, Rhinehart \& Winston.

Johnston, L.D., Bachman, J.G., and O'Malley, P.M. (1976, I98I, 1986, 199I, I992, 1993,

1994, 1995). Monitoring the future: Questionnaire responses from the nation's high school Seniors. Ann Arbor, MI: Institute for Social Research, The University of Michigan.

King, P. E. (2003). Religion and identity: The role of ideological, social, and spiritual

contexts. Applied Developmental Science, 7(3), 197204.

Koenig, H. G. (2007). Spirituality in patient care: Why, how, when, and what (2nd ed).

Philadelphia: Templeton Foundation Press. 
Kvarfordt, C. L., \& Sheridan, M. J. (2007). The role of religion and spirituality in

working with children and adolescents: Results of a national survey. Journal of Religion \& Spirituality in Social Work, 26(3), I-23.

Lam, P. (2002). As the flocks gather: How religion affects voluntary

association participation. Journal for the Scientific Study of Religion, 4I: 405-422.

Lerner, J. V., Hertzog, C., Hooker, K. A., Hassibi, M., \& Thomas, A. (1988).

A longitudinal study of negative emotional/behavioural states and adjustment from early childhood through adolescence. Child Development, 59, 356-366.

Lerner, R. M. (2002). Concepts and theories of human development (3rd ed.). Mahwah,

NJ: Erlbaum.

Lerner, R. M., Dowling, E. M., \& Anderson, P. M. (In press). Positive youth

development: Thriving as a basis of personhood and civil society. In Wagner, L. \& Furrow, J. (Eds.). Beyond the self: Perspectives on transcendence and identity development.

Long, K.A. and Boik, R.J. (1993). Predicting alcohol use among rural

children: a longitudinal study. Nursing Research, 42(2): 79-86.

Madu, S.N. \& Matla, M.P. (2003). Illicit drug use, cigarette smoking and alcohol

drinking behaviour among a sample of high school adolescents in the Pietersburg area of the Northern Province, South Africa. Journal of Adolescence, 26(I): |2|-|36.

Mann, J.R., Mckeown, R.E., Bacon, J., Vesselinov, R. and Bush, F. (2007).

Religiosity, Spirituality, and Tobacco Use by Pregnant Women. Southern Medical Journal, I00 (9): 867872.

Morojele, N.K., Brook, J.S., Kachieng'A, M.A. (2006). Perceptions of sexual risk

behaviours and substance abuse among adolescents in South Africa: A qualitative investigation. AIDS Care: Psychological and Socio-medical Aspects of AIDS/HIV.

I8 (3): 215-219.

Morojele, N.K., Kachieng'a, M.A., Mokoko, E., Nkoko, M.A., Parry, C.D.M. \&

Nkowane, 2006. Alcohol use and sexual behaviour among risky drinkers and bar and shebeen patrons in Gauteng Province, South Africa. Social Science and Medicine, 62: 217-227.

Nusbaumer, M.R. (198I). Religious affiliation and abstinence: a fifteen year change.

J. Stud. Alcohol, 42: |27-I3|.
Obot, I. S., Kaburi, G. S. \& Ibanga, A. J. (2003). Substance use and other risky behaviours

of secondary school students in a Nigerian urban area. African Journal of Drug and Icohol Studies, 2(I\&2):57-65.

Onya, H., Tessere, A. Myers, B., and Flisher, A. (20I2). Adolescent alcohol Use in rural

South African high schools. African Journal of Psychiatry, 15: 352-357.

Peltzer, K., Malaka, D.W., and Phaswana, N. (2002). Sociodemographic Factors,

Religiosity, Academic Performance, and Substance Use among First-year University Students in South Africa. Psychological Reports, 91:I05-II 3.

Pergamit, M.R., Huang, L., and Lane, J. (200I). The long term impact of adolescent risky

behaviors and family environment [Electronic version. Washington, DC: Office of the Assistant Secretary for Planning and Evaluation, US Department of Health and Human Services. Retrieved September 10, 2004, from http://aspe.hhs.gov/hsp/riskybehav0 I.

Pettifor, A.E., Rees, H.V., Steffenson A., HlongwaMadikizela L, MacPhail, C. (2004).

HIV and sexual behaviour among young South Africans: a national survey of 15-24 year olds. See more at: http://www.popline.org/node/253955\#sthash.cV DxS5UM.dpuf.

Pew Research Center. (2015). The Future of World Religions: Population Growth

Projections, 20I0-2050.

PrüDderman, A. and Flisher, A.J. (2008). Adolescent methamphetamine use and sexual

risk behaviour in secondary school students in Cape Town, South Africa.

Drug and Alcohol Review, 27(6): 687-692

Ream, G. L. (2003). Religion's Role in the Development of Youth.

http://demoiselle2femme.org

Regnerus, M.K. and Smith, C. (2005). Selection Effects in Studies of Religious Influence.

Review of Religious Research, 47(I): 23-50.

Reich, H. (1999). Spiritual and religious development: Transcendence and transformations of

the self. In K.H. Reich, F.K. Oser \& W.G. Scarlett (Eds.) Psychological studies on spiritual and religious development: Being human: The case of religion, Vol. 2. (pp. 57-82). Scottsdale, AZ: Pabst Science Publishers.

Rohrbaugh, J. and Jessor, R. (1975). Religiosity in youth: A personal control against deviant behavior. Journal of personality, 43: I36-I55.

Roth, J., Brooks-Gunn, J., Murray, L., \& Foster, W. (1998). Promoting healthy 
adolescents: Synthesis of youth development program evaluations. Journal of Research on Adolescence, 8, 423-459.

opportunities for youth development: The what, why, when, where, and who of citizenship development. Applied Developmental Science, 6(4), 264-272.

Shuler, P., Gelberg, L., \& Brown, M. (1994). The effects of spiritual/religious practices

on psychological well-being among inner city homeless women. Nurse Practitioner Forum, 5(2), 106-113.

Sinha, J.W., Cnaan, R. A. \& Gelles, R. W. (2007). Adolescent Risk Behaviours and Religion:

Findings from a National Study. http:repository.upenn.edu/

Sloan, R.P.Bagiella, E., and Powell, T. (1999). Religion, Spirituality, and medicine.

Lancet, 353: 664-667.

Smithline, C. (2000). Spirituality as a protective factor against adolescent substance

abuse (Unpublished doctoral dissertation). United States International University, Ann Arbor, Michigan.

Smith, C. and Denton, M.L. (2005). Soul searching: The religious and spiritual lives

of American teenagers. New York: Oxford University Press.

Spilka, B. 199I. Religion and Adolescence. In R.M Lerner et al. (Eds.),

Encyclopedia of Adolescence. New York. Garland.

Sutherland, I. \& Shepherd, J. P. (200I). Social Dimensions of Adolescent Substance Abuse.

Addiction 96: 445-458.

Wallace, J.M., Jr. and Williams, D.R. (1997). Religion and adolescent

\footnotetext{
'The cases in the "Other" category were very small in each case hence the decision to combine them against Protestants and Catholics.

ii It is significant to note that Amoateng et al.'s (2006) study and many of the studies in the US were based on high school samples while the current study was based on a sample of college students. It is therefore possible that parental socioeconomic status interacts differently with youth in different age groups.
}

Sherrod, L., Flanagan, C. \& Youniss, J. (2002). Dimensions of citizenship and

health-compromising behaviour. In J. Shulenberg, J.L. Maggs, \& K. Hurrelmann (Eds.), Health risks and developmental transitions during adolescence (pp.444-468). New York: Cambridge University Press.

Ward, C.L., Mertens, J.R., Flisher, A.J., Bresick, G.F., Sterling, S.A., Little, F. and

Weisner, C.M. (2008). Prevalence and Correlates of Substance Use among South African Primary Care Clinic Patients. Substance Use \& Misuse, 43(10): |395- | 410.

Weber, M. (1992). The Protestant Ethic and the Spirit of Capitalism. London: Routledge

(First published in German 1904-5).

Wheeler, W. (2000). Emerging organizational theory and the youth development

organization. Applied Developmental Science, 4, Supplement I, 47-54.

Wild, L.G., Flisher, A.J., Bhana, A., \& Lombard, C. (2008). Associations among

adolescent risk behaviours and self-esteem in six domains. Journal of Child Psychology and Psychiatry, 45: |454-| 467.

Wilson, M. (2004). A part of you so deep: What vulnerable adolescents have to say about

spirituality. Boxboro, MA: New England Network for Child, Youth and Family Services.

Yust, K. M., Johnson, A. N., Sasso, S. E., \& Roehlkepartain, E. E. (Eds.). (2006).

Nurturing child and adolescent spirituality: Perspectives from the world's religious traditions. Lanham, MD: Rowman \& Littlefield 